\title{
Gaia
}

Revue interdisciplinaire sur la Grèce archaïque

\section{The Genealogy of Dionysus: Bacchylides 19 and Eumelus' Europia}

La généalogie de Dionysos: Bacchylide 19 et l'Europia d'Eumélos

\section{Marios Skempis}

\section{(2) OpenEdition \\ 1 Journals}

Electronic version

URL: https://journals.openedition.org/gaia/512

DOI: $10.4000 /$ gaia. 512

ISSN: 2275-4776

\section{Publisher}

UGA Éditions/Université Grenoble Alpes

\section{Printed version}

ISBN: 978-2-37747-199-7

ISSN: 1287-3349

\section{Electronic reference}

Marios Skempis, "The Genealogy of Dionysus: Bacchylides 19 and Eumelus' Europia", Gaia [Online], 22-23 | 2020, Online since 30 June 2020, connection on 09 December 2021. URL: http:// journals.openedition.org/gaia/512 ; DOI: https://doi.org/10.4000/gaia.512

This text was automatically generated on 9 December 2021.

Gaia. Revue interdisciplinaire sur la Grèce archaïque 


\section{The Genealogy of Dionysus: Bacchylides 19 and Eumelus' Europia}

La généalogie de Dionysos: Bacchylide 19 et l'Europia d'Eumélos

Marios Skempis

1 Bacchylides' relation to the Epic Cycle is an issue under-appreciated in the study of classical scholarship, the more so since modern Standardwerke such as Martin West's The Epic Cycle and Marco Fantuzzi and Christos Tsagalis' The Greek Epic Cycle and Its Reception: A Companion are unwilling to engage in discussions about the Cycle's impact on this poet. ${ }^{1}$ A look at the surviving Dithyrambs in particular shows that Bacchylides appropriates the Epic Cycle more thoroughly than one expects: Bacchylides 15 reworks the Cypria's Request for Helen's Return (arg. $10 \mathrm{~W}$ ); Bacchylides 16 alludes to Creophylus' Sack of Oechalia; Bacchylides 17 and 18 are instantiations of mythical episodes plausibly excerpted from an archaic Theseid; Bacchylides 19 opens and ends its mythical section with a circular mannerism that echoes the Thebaid's incipit (fr. $1 \mathrm{~W}$ ); Bacchylides 20 focuses on Marpessa, a minor figure from the Meleager story in Iliad 9; Bacchylides 23 has the story of Cassandra inspired by the Sack of Ilion (args. 1; 3 W); in Bacchylides 25, the story of Meleager refers to Heracles, who must have featured in the Minyas next to residents of Hades (frs. 3-7 W); Bacchylides 27 glimpses into Chiron's relationship to Achilles, which is founded ahead of the Trojan War according to the Cypria (fr. $4 \mathrm{~W}$ ). The plethora of examples encourages an extensive treatment of the topic, which is not my intention in this article. What I intend to do is to consider the end of the Io story in Bacchylides 19 with a view to how the dithyrambic poet shapes his narrative with respect to the Epic Cycle. ${ }^{2}$

2 The story of Io' release from Argus and union with Zeus at the Nile ends with a macrogenealogy of Dionysus (B. 19.37-51): 


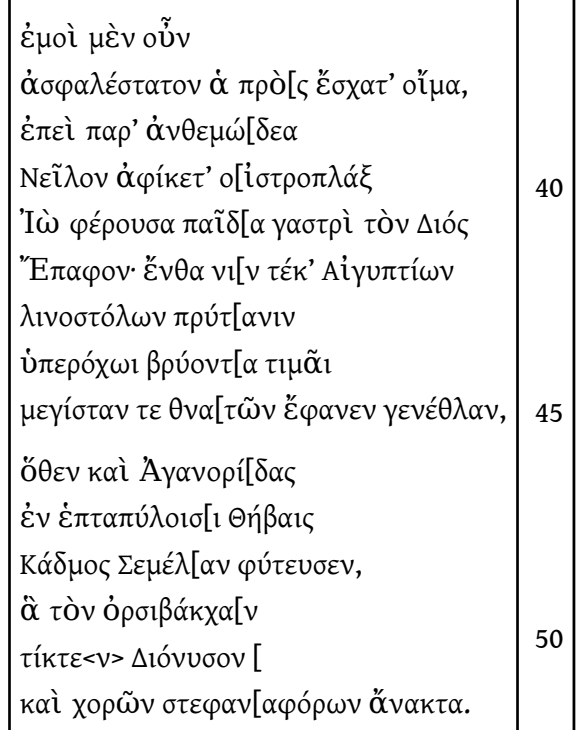

First in line is Epaphus, second Cadmus, and third Dionysus. What is most unusual in this genealogical concatenation is that, as one moves from the first descendant of Io to the second, there is a noticable gap. ${ }^{3}$ The omitted macro-progeny of Epaphus, which can be deduced from Apollodorus, is as follows:

Epaphus and Memphis $\rightarrow$ Libye ([Apollod.] 2.10)

Libye and Poseidon $\rightarrow$ Agenor, Belus ([Apollod.] 2.10)

Agenor and Telephassa $\rightarrow$ Europa, Cadmus, Phoenix, Cilix ([Apollod.] 3.1-2)

Cadmus and Harmonia $\rightarrow$ Autonoe, Ino, Semele, Agaue, Polydorus ([Apollod.] 3.21-

6)

Bacchylides' version of Epaphus' relation to Cadmus suppresses four generational gradations in a way that leaves many questions about the choice of this omission.

The genealogical connection of Io and Dionysus is unattested, except for one source. Diodorus tags three Dionysuses, each of whom has a different genealogy (3.74.1-2):

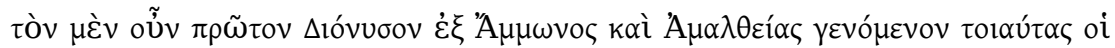

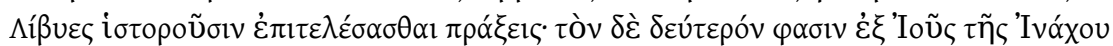

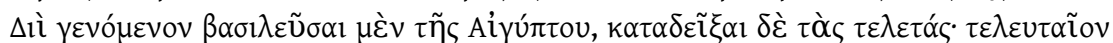

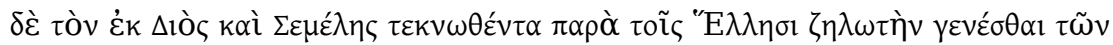

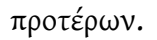

What is significant about this tripartition ${ }^{4}$ is that the second genealogy acknowledges Io, Inachus' daughter, as mother of Dionysus and Zeus as his father. In rationalizing terms, this deviant maternal filiation is a short cut of the four generational gradations that span from Epaphus to Cadmus. ${ }^{5}$ The second account has no precedence, ${ }^{6}$ so we cannot know the text it goes back to. The only narrative that seems to be aware of it is the closing section of Bacchylides 19, which recognizes Io as Dionysus' foremother. It is likely that Bacchylides alludes to this deviant maternal filiation when he sets up a macro-link between Io and Dionysus.

Leaving the Io/Dionysus nexus aside, the mythological account of Diodorus delves into the story of Dionysus by introducing several chronological incoherences, which range from the Lycurgus episode to his birth. Europe forms a common link that devises a frame for the way Diodorus treats these two seminal episodes. The ensuing macrosection sets emphasis on how Dionysus had to face problems of cult integration when 
he tried to make his way from Asia to Europe. ${ }^{7}$ What started out as friendship with Lycurgus the ruler of Thrace ended up in a conflict that tagged the Thracian king an opponent of the cult of Dionysus, who fought against the Bacchants (D. S. 3.65.4-7). The framing reference to Europe tells of how Cadmus the son of Phoenician Agenor was commissioned to fetch the girl, who was kidnapped by Zeus. His search led Cadmus to Boeotia where he settled, married Harmonia, and begot Semele, Ino, Autonoe, Agaue, and Polydorus. ${ }^{8}$ The story of Cadmus' quest for Europe ${ }^{9}$ gives rise to the story of how Semele was struck by lightning in her union with Zeus. The offspring of this union, Dionysus, was taken care of by Zeus, who entrusted the baby-boy to the nymphs of Nyse, which is located between Phoenicia and the Nile, through Hermes' intervention (D. S. 4.2.1-5). The Europe frame of Diodorus is reflected in the Europia of Eumelus that deals with her romance with Zeus (fr. $26 \mathrm{~W}$ ), one generational gradation before the birth of Dionysus, and with the Lycurgus episode (fr. 27 W), which signifies Dionysus' tense relation to the spatiality of Europe. ${ }^{10}$

Diodorus' account about the connection between Cadmus and Dionysus is genealogically construed. The Europe frame does not hinge on Dionysus himself, but extends to him by drawing on the genealogical link of Cadmus and Dionysus. The closing section of Bacchylides 19 is in keeping with the genealogical connection of Cadmus and Dionysus. With a view to the genealogical tripartition of Dionysus in Diodorus, the end of Bacchylides 19 is aware of the two (out of three) genealogical variants for Dionysus. These variants are genealogically concatenated in rationalizing manner that creates generational coherence..$^{11}$ The macro-genealogical emphasis that Bacchylides lays on Io and Dionysus, is further bolstered by the gadfly motif, which

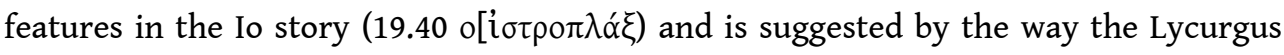

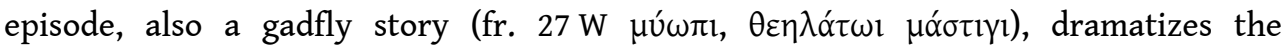

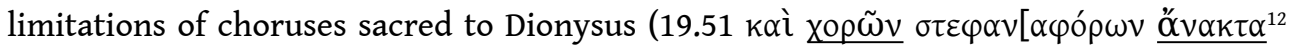

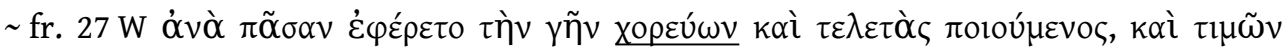

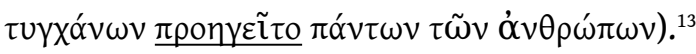

9 Concerning Quellenforschung, I want to make two points, one about Diodorus' relation to Eumelus and a second about the impact of Eumelus on Bacchylides 19:

1. Diodorus' account of Dionysus refers to the Titanomachy (3.74.6), the theme of a poem traditionally ascribed to Eumelus. ${ }^{14}$ Scholia D on Homer's Iliad (6.131) attest that the Lycurgus episode, which Diodorus mentions in what I have termed Europe frame, is recounted in the Europia of Eumelus. The birth of Dionysus, which springs out of the genealogical link with Cadmus in Diodorus' Europe frame (4.2.1-3), ought to have been part of Eumelus' Europia, a genealogical poem that narrated the events after Zeus' union with Europe.

2. The arrangement of Dionysus' ancestry in genealogical sequence, ${ }^{15}$ which the closing section

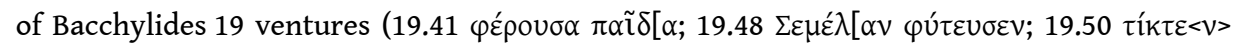
$\Delta$ ióvuбov), is plausibly based on Eumelus' Europia for the following reasons: (a) the nuclear story of bovine Io in the opening Epaphus-entry is one of prosecution by a gadfly just as Dionysus is pursued by a gadfly in the Lycurgus episode; (b) the Agenorid cue in the Cadmusentry (19.46) shows a tendency toward acknowledging the genealogical environment in which Europe, a figure similar to Io in terms of the bovine idiom ${ }^{16}$ and the point of reference in the Europia (fr. 26 W), is situated; (c) the Dionysus-entry stresses the capacity of the god to rouse Bacchants and preside over their dances, two features that the Europia presents e negativo (fr. $27 \mathrm{~W}$ ). 
Considering that Eumelus' Europia has a genealogical tinge, Bacchylides' predilection to end the Io story in a way that points to the Agenorid stemma and its own ancestry, is a noticeable thematic affinity: the dithyrambic narrative recounts Dionysus' birth (19.50) in a context that echoes the Lycurgus episode (19.49-51) just as the summary of the Lycurgus episode attributed to Eumelus' Europia opens with an acknowledgement of Dionysus' descent from Zeus and Semele ${ }^{17}$-this means that the Europia must have narrated both Dionysus' birth, in tune with the Agenorid stemma, and his adventure with Lycurgus. These two episodes constitute the Asian cycle of Dionysus before he enters the Greek world.

One may hasten to ask why it is important to recuperate a set of allusions to Eumelus' Europia in a dithyrambic poem such as Bacchylides $19,{ }^{18}$ which does not extol, but closes with Dionysus. Instead of treading the usual path of choosing a Dionysiac plotline, Bacchylides innovates by investing on para-Dionysiac thematics. ${ }^{19}$ Eumelus' Europia serves this goal in a twofold way, through the genealogically conditioned birth of Dionysus and the Lycurgus episode, and departs from Europe's union with Zeus, a story parallel to that of Io.

\section{BIBLIOGRAPHY}

BERNABÉ Alberto, "Homero y Eumelo. Dos versiones del mito de Licurgo", in J. F. González Castro \& J. de la Villa Polo (eds), Perfiles de Grecia y Roma II, Madrid, Sociedad Española de Estudios Clásicos, 2010, pp. 346-52.

BERNABÉ Alberto, "Bacchide, Dioniso e un frammento dell'Europia di Eumelo", in P. Angeli Bernardini (ed.), Corinto: luogo di azione e luogo di racconto, Pisa/Roma, Fabrizio Serra, 2013a, pp. 51-61.

BERNABÉ Alberto, “Dioniso en la épica griega arcaica”, in A. Bernabé, A. I. Jiménez San Cristóbal \& M. A. Santamaría (eds), Dioniso. Los orígenes. Textos e imágenes de Dioniso y lo dionisíaco en la Grecia antigua, Madrid, Liceus, Servicios de Gestión y Comunicación, 2013b, pp. 29-85.

BOWRA Cecil Maurice, “The Daughters of Asopus”, Hermes, 73, 1938, pp. 213-21.

CARPENTER Thomas H., "On the Beardless Dionysus", in T. H. Carpenter \& C. A. Faraone (eds), Masks of Dionysus, Ithaca/London, Cornell University Press, 1993, pp. 185-206.

D’ALESSIO Giambattista, “Theogony and Titanomachy”, in M. Fantuzzi \& C. Tsagalis (eds), The Greek Epic Cycle and its Ancient Reception: A Companion, Cambridge, Cambridge University Press, 2015, pp. 199-212.

DEBIASI Andrea, L'epica perduta: Eumelo, il Ciclo, l'occidente, Roma, L'Erma di Bretshneider, 2004. DEBIASI Andrea, Eumelo: Un poeta per Corinto. Con ulteriori divagazioni epiche, Roma, L"'Erma" di Bretshneider, 2015.

FANTUZZI Marco \& TSAGALIS Christos (eds), The Greek Epic Cycle and its Ancient Reception: A Companion, Cambridge, Cambridge University Press, 2015.

Gaia, 22-23 | 2020 
HALL Edith, “When Is a Myth Not a Myth? Bernal's “Ancient Model”, Arethusa, 25, 1992, pp. 181201.

HUXLEY George L., Greek Epic Poetry: From Eumelos to Panyassis, London, Faber \& Faber, 1969.

LECOMTE Catherine, "L'Eủ $\rho \omega \pi i ́ \alpha$ d'Eumélos de Corinthe", in R. Poignault \& O. Walter-de Croizant (eds), D'Europe à l'Europe 1 : Le mythe d'Europe, Tours, Centre de recherches A. Piganiol, 1998, pp. 71-9.

MAEHLER Herwig, Die Lieder des Bakchylides. Zweiter Teil: Die Dithyramben und Fragmente, Leiden/ New York/Köln, Brill, 1997.

OLIVIERI Oretta, “Asopo, fiume 'interregionale': le tradizioni locali nell'epica di Eumelo e nella poesia lirica arcaica”, in P. Angeli Bernardini (ed.), L'epos minore, le tradizioni locali e la poesia arcaica, Pisa/Roma, Fabrizio Serra, 2007, pp. 15-24.

SKEMPIS Marios, "Review of M. Fantuzzi \& C. Tsagalis (eds), The Greek Epic Cycle and Its Ancient Reception: A Companion, Cambridge, 2015”, MH, 73, 2016, pp. 223-4.

RONDOT Vincent, “Le dieu à la bipenne, c'est Lycurge”, REgypt, 52, 2001, pp. 219-49.

TOPPER Kathryn R., "Dionysos Comes to Thrace: The Metaphor of Corrupted Sacrifice and the Introduction of Dionysian Cult in Images of Lykourgos' Madness”, Arethusa, 48, 2015, pp. 139-72.

TSAGALIS Christos, The Oral Palimpsest: Exploring Intertextuality in the Homeric Epics, Cambridge, Mass./London, Harvard University Press, 2008.

TSAGALIS Christos, From Listeners to Viewers: Space in the Iliad, Cambridge, Mass./London, Harvard University Press, 2012.

TSAGALIS Christos, Early Greek Epic Fragments 1: Antiquarian and Genealogical Epic, Berlin/Boston, De Gruyter, 2017.

UNTERSTEINER Mario, "Eumelo di Corinto", Antiquitas, 6-7, 1951-2, pp. 3-13 [= Scritti minori: studi di letteratura e filosofia greca, Brescia, Paideia editrice, 1971, pp. 165-79].

WEST Martin L., ““Eumelos': A Corinthian Epic Cycle?”, JHS, 122, 2002, pp. 109-33.

WEST Martin L., Greek Epic Fragments: From the Seventh to the Fifth Centuries BC, Cambridge, Mass./ London, Harvard University Press, 2003.

WEST Martin L., The Epic Cycle: A Commentary on the Lost Troy Epics, Oxford, Oxford University Press, 2013.

WILAMOWITZ-MOELLENDORFF Ulrich von, “The Poems of Bacchylides, ed. by Kenyon”, GGA, 160, 1898, pp. 125-60.

\section{NOTES}

1. West $(2013,45)$. Fantuzzi \& Tsagalis (2015) devote no chapter to the Cycle' influence on Bacchylides; for a quibble, see Skempis $(2016,224)$.

2. Here I follow West $(2002,109)$ in his belief that the Titanomachy, the Corinthiaca, and the Europia of Eumelus formed a "Corinthian Epic Cycle", and I treat the latter epic as part and parcel of the Epic Cycle.

3. Maehler (1997, 260-1) finds no fault with this.

4. The tripartition is situational because later on Diodorus mentions a fourth genealogy of Dionysus the offspring of Zeus and Persephone (4.4.1). See also D. S. 3.64.1. 
5. According to Hall $(1992,187)$, "there may have existed a whole [...] mythical tradition about Io's descendants".

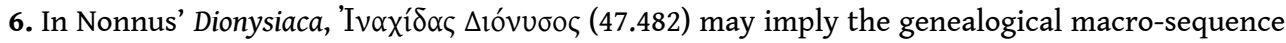
that Bacchylides outlines. Note that, according to Debiasi $(2015,69-150)$, the Dionysiaca include several allusions to Eumelus.

7. For the Lycurgus episode in Eumelus, see Tsagalis (2008, 1, 6, 18, 28), Tsagalis (2017, 141-4), Bernabé (2010; 2013a). Lycurgus' encounter with Dionysus is told in the Iliad (6.130-40): see Carpenter (1993, 197-8), Rondot (2001), Tsagalis (2008, 2-13), Tsagalis (2012, 248-51), Bernabé (2010), Topper $(2015,153-8)$.

8. This stemma must have been part of Eumelus' Europia. See Debiasi $(2015,86-7)$, Tsagalis (2017, 134).

9. The consultation of the Delphic oracle by Cadmus during this quest may well be the theme of fr. 28 W. See Lecomte $(1998,74)$, West $(2002,127)$.

10. On Europia in general, see Huxley $(1969,75-6)$, Lecomte (1998), West $(2002,126-8)$, West (2003, 29-31), Debiasi (2004, 24-6), Debiasi (2015, 76-80), Tsagalis $(2017,132-6)$.

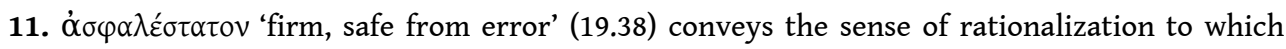
Bacchylides subjects Dionysus' macro-descent from Io.

12. The line is supplemented by Wilamowitz-Moellendorff $(1898,143)$ and accepted by all modern editors.

13. It may be so that scholarship on dithyramb neglects the general character of the utterance and tends to set it in the context of dithyramb performance (the choruses of Dionysus being circular choruses that perform the dithyramb).

14. Cf. D’Alessio (2015, 209, n. 48).

15. For Dionysiac features in Eumelus' Europia, see Untersteiner (1951-2), Bernabé (2013a) and (2013b, 54-7).

16. On the bovine element in the Europia, see Untersteiner (1951-2).

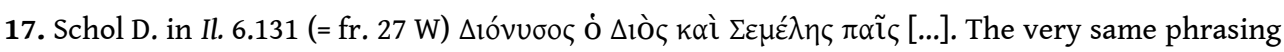
that enciphers the narrative rendition of Dionysus' birth (otherwise the name Dionysus would

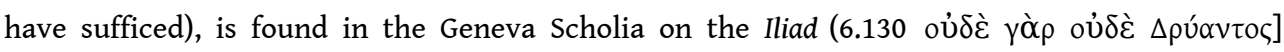

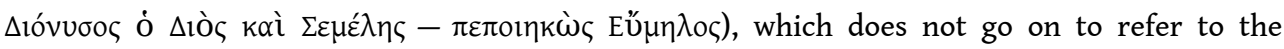
Lycurgus episode.

18. For the use of material (the daughters of Asopus) already treated by Eumelus in Bacchylides 9 , see Bowra $(1938,216-9)$, Olivieri (2007), West $(2002,126)$.

19. The Egyptianizing contexts of Io's destination, the Nile, and Dionysus' birth at Nyse show how the two stories weld together in a dithyrambic narrative.

\section{ABSTRACTS}

I argue that in the end of Bacchylides 19 the genealogy of Dionysus echoes the Europia of Eumelus. My argument is an example for how para-Dionysiac theme works in Bacchylides' dithyramb.

J'affirme qu'à la fin de Bacchylide 19 la généalogie de Dionysos reprend l'Europia d'Eumélos. Mon argument est un exemple de comment le thème para-dionysiaque fonctionne dans le dithyrambe de Bacchylide. 
INDEX

Mots-clés: Eumélos, Bacchylide, Dionysos

Keywords: Eumelos, Bacchylides, Dionysos

\section{AUTHOR}

\section{MARIOS SKEMPIS}

Chercheur indépendant

marios.skempis@gmail.com 